\title{
Music as a Language of Social Harmony in Tenggerese Community
}

\author{
Okta Hadi Nurcahyono \\ Faculty of Teacher Training and Education, SebelasMaret University, Surakarta, Indonesia \\ okta.hadi@staff.uns.ac.id
}

\begin{abstract}
Every community has value order narrated as the form of local wisdom in many aspects of life, including art. This article described local wisdom in the form of music art among Youths in the Tenggerese Custom Community. This article is the product of ethnographic research conducted by the author in Tenggerese Community, Tosari Sub District, Pasuruan, East Java. The data of the research was collected through participatory observation, in-depth interviews, and focus group discussion (FGD). The data obtained were then validated using source triangulation. Meanwhile, to analyze the theory, this study employed A.R. Radcliffe Brown's Structure and Function theory approach. The result of the research showed that the Young Tenggerese Community's thinking construction, particularly in Tosari, was highly affected by customary values, including art and particularly music art. There was concept or value in Tenggerese customary community underlying its community's life attitude, "anteng-seger" (Tengger) concept meaning peaceful and prosperous. Anteng value can also be defined as calm and not talking too much, which can be elaborated again into the concept of "SepiingGunem, RameingGawe" meaning "talk less do more". Majority Tenggerese youths love art, particularly music art; one of their favorite music is patrol music.
\end{abstract}

Keywords: youth, music, and social harmonization

\section{INTRODUCTION}

The customary community is a group of society with various unique customs they have. Many studies have been conducted in the anthropology field focusing on the customary community. Customary community development is something coloring the early existence of anthropology. In the mid 19th century, anthropologists focused their study on developing tribal communities (customary community). For example, L.H. Morgan, known for writing a book entitled "Ancient Society" in 1877, studied the evolution of the community by observing the custom in Indian people. In Indonesia, the customary community began to be defined in the state's political stag since the first Community Congress in 1999[1]. Indigenous people are members of the community living together based on origin hereditarily in an area constituting customary areas with sovereignty over land and natural wealth management, social and cultural life governed by value order and customary norm, and customary institution to manage life sustainability. In such a definition, the Tenggerese community can be categorized into the customary community. Tenggerese community is a customary community living in Taman NasionalBromoTenggerSemeru (TNBTS); they live in the slopes of Bromo Mountains. Geographic conditions and environments where they live affect value order and custom widely. 
One of local wisdom the customary community has is traditional music. In addition to local wisdom, traditional music revives a community's collective memory related to collective cultural identity[2]. This identity roots in a group of people's collective life experience. Collective cultural identity indeed can be constructed through historical experience or cultural history - a chronicle culture - memorized, narrated, and collected collectively by all members of the community [3]. John M. O'Connell in his book entitled "Music and conflict" in 2010 explained that music is more than language, that can provide the best media to explain the character of conflict and to evaluate the quality of conflict resolution [4]. For instance, mentioned the term "harmony" very inherent to music theory concept. Harmony is one of the expressions in conflict transformation scenario. In music theory, the harmony results from different tone combinations. It can refer to the combination of different cultural identities of each individual becoming the collective cultural identity.

Many studies discuss music and social harmony[5]-[9]. This research focused on a social harmony process created by a collective cultural creating process, music. It is in line with Lestari research [10] seeing the role of music as a media of peace in Maluku. Similarly, in the methodological matter, this study is similar to Tika's[10]study employing ethnographic research approach seeing the music problem in its reality. However, this study is different as it takes the aspect of youths in portraying music as a social harmony language.

The development of a community is inseparable from the existence of youths within it, including the customary community. The youth plays an important role as the agent of change within the community. Satries[11], said that history has proved that youth is one of the pillars playing a considerable part in the nation and state's life journey so that a state's advance or deterioration is determined by the youths' thinking and active contribution in the state. Indonesia, for example, as a nation and state entity, cannot be independent of the youth's role in the independence process. It indicates how central the role of youths is to the community development, because youths have a basic characteristic, being responsive to the change. Previous studies conducted on youth-focused on youth as transition, youth as identity, youth as action, youth as a cultural practice, and youth and cultural creator [12].This article studies the theme of youth in cultural practice, particularly in Tenggerese customary community.

\section{METHOD}

This study was a product of field research conducted by the author. Field research was conducted in the Tosari sub-district, Pasuruan Regency, East Java, as the residence of the Tenggerese Customary Community. This study was qualitative research with ethnographic design [13]. The descriptive ethnographic design was used in this research to understand the peculiarity of the Tenggerese Tribal Customary Community in Tosari Sub District area, particularly in artistic practice and harmonization amid the community. The author collected data through firstly participatory observation, by observing the youth's artistic activity, for example, when they assemble, practice, and hold a customary ceremony. Secondly, in-depth interview was conducted with Customary Leader (Dukun), Head of Village, and youth leader. Thirdly, focus group discussion was conducted with the representatives of customary and youth leaders throughout the Tosari Sub District.

To improve the validity of field data, the source triangulation technique was used. This source triangulation technique was used using crosschecking the data resulting from the 
research and comparing it with that from other sources like previous studies. Data analysis was conducted using descriptive qualitative data analysis encompassing three stages: data collection, data classification by data collection technique and problem statement, and data verification. Meanwhile, the theoretical analysis was conducted using R Radcliffe Brown's structural functionalism theory [14] in portraying music reality as a social harmony language within the Tenggeresecustomary community.

\section{RESULTAND DISCUSSION}

Community is a dynamic and interdependent organization and association through cultural values, moreover in the customary community. The customary community contains many value systems rooting and implemented in life. The value system is called local wisdom. Local wisdom in the community goes down from one generation to the next through oral tradition or folklore. So many folklores are existent within the community and believed to be a truth and value contained in the community's way as a life philosophy. Tenggerese customary community, for example, was united as the descent of JokoSeger and RoroAnteng, and then "Tengger" value can also be defined as anteng and seger meaning peaceful and prosperous. This value becomes Tengger tribal customary community's life philosophy.

Tosari is a sub-district belonging to Pasuruan Regency's administrative territory. Meanwhile, culturally Tosari is one of 36 (thirty-six) villages located in Tengger customary territory, exactly in sebrangkulon (brangkulon) meaning in the west. Thus, Tosari people's life is highly dependent on Tenggerese cultural values. Geographically, Tosari is located in the slope of Tengger Mountains or exactly in Taman NasionalBromoTenggerSemeru (TNBTS). Whereas, Tosari Sub District area is divided into 9 villages: Tosari, Sedaeng, Wonokitri, Baledono, Molorejo, Kandangan, Podokoyo, and Ngadiwono. Each of the villages in Tosari has distinctive characteristics, including its social structure and community diversity. Nevertheless, a cultural consensus unites them, that they are Tenggerese, the descent of JokoSeger and RoroAnteng.

Besides, one thing equating all villages in Tengger territory is local leadership. Besides, to be led by the Head of Village in the bureaucratic structure just like in other common villages in Indonesia, Tosari is also led culturally by Customary Leader (Tribal Chief). In contrast to a tribal chief or customary leader in other areas, a dukun in Tengger plays dual roles: social and spiritual. A dukunadat's social role is to be a mediator of community members in social governmental affairs. Besides, a dukun also has the authority to make an important decision in terms of the calendar, rule, and customary sanction. Besides, the important duty of a dukunadat in Tengger is to maintain the harmonization between human and his God, human between humans, and between human and nature. In the process of playing his spiritual role, dukun gets additional predicate, DukunPandita. A dukunPandita serves to lead the customary ceremony and Hindu religious ceremony in the temple (Pura). Thus, a dukun should recite thousands of spells obligatorily.

Custom and habit result from joint principles and ideas composing a culture, and a series of related theories exploring those principles [15]. Tenggerese Community's life in Tosari has some concepts or value orders underlying their life attitude. Tenggerese's life principle is upheld intensely; Tengger is defined as a local community, standing for "antengseger" (Tengger) meaning peaceful and prosperous. This antengseger principle is taken from mythology developing within community, the origin of Mount Bromo taken from mythology 
JokoSeger and RoroAnteng. Concept "anteng" is elaborated in Tenggerese customary community's life principle, "SepiingGunem, RameingGawe" meaning "talk less do more".

Collective mentality is composed of reciprocal effect of individual's thoughts resulting from the group's membership and participation in collective activity [15]. As a part of Tenggerese Customary Community, Tenggerese youths must implement their custom amid inevitable modernization. They are obliged to follow the rituals existing, either customary or religious ones. On the 14th and 15th dates of Kasodo month (Tengger calendar), youths are preoccupied with preparing YadnyaKasada Customary Rite. One day before they would be preoccupied with preparing ongkek to welcome the customary rite. They will float the ongkek on Mount Bromo's cauldron during Kasada. So are other customary rites such as unan-unan and entas-entas.

In addition to preparing ongkek to be brought into the cauldron during "YadnyaKasada" rite, Tenggerese youths also prepare music instruments they would bring with them. They brought music instruments like simpler gamelan played by walk. The music instrument includes kendang, gong, and serompet. One music instrument distinguishing it from other common gamelan is serompet. This music instrument is a type of blown music instrument, a kind of trumpet made of pedu wood with dragon carving on its rod. This music instrument is used at certain moments only, for example in the customary rite. Most Tenggerese gamelan music players are youths. This music performance is expected to grow collective characteristics and mentality. Music is expected to internalize customary values as the collective mentality of Tenggerese youth. It, according to Radcliffe Brown [14], is a part of the cell regeneration process, in which new cells appear to replace the old dead ones. Thus, this presence of new cells will enable the system of the organism to run.

The condition of Tenggerese youth today still gives an expectation to the existence of customary values. Community education is undertaken through religious education within society. Religious education in Tengger can transmit belief system values to children as collective characteristics. In addition to community education, family education becomes very important. The family affects considerably the creation of children's behavior, because, through family, children will know the society where they live and the family's value and culture that will later affect them when they go out of their family [16]. Therefore, in education as a process of transmitting collective (customary) values, the youths cannot stand to be a distinctive entity. It is because, according to Radcliffe Brown, the entities will establish a relationship that will unite the one and another. Each of the entities has its function and takes care of each other, thereby will create a structural unity.

\subsection{Collective Characteristics of Tenggerese Youth}

Custom and culture are the expressions of "people spirit" or collective mentality becoming the foundation [15]. The implication of people's spirit is reflected in language, belief, and custom as the collective characteristics of the social group and as the foundation of all mental activities. The collective mentality is composed of the reciprocal effect of an individual's thoughts resulting from the group's membership and participation in collective activity [15]. As a part of Tenggerese Customary Community, Tenggerese youths must implement their custom amid inevitable modernization. They are obliged to follow the rituals existing, either customary or religious ones. On the 14th and 15th dates of Kasodomonth (Tengger calendar), youths are preoccupied with preparing "YadnyaKasada" Customary Rite. One day before they would be preoccupied with preparing ongkek to welcome the customary 
rite. They will float the ongkek on Mount Bromo's cauldron during Kasada. So are other customary rites such as unan-unan and entas-entas.

In addition to preparing ongkek to be brought into the cauldron during "YadnyaKasada" rite, Tenggerese youths also prepare music instruments they would bring with them. They brought music instruments like simpler gamelan played by walk. The music instrument includes kendang, gong, and serompet. One music instrument distinguishing it from other common gamelan is serompet. This music instrument is a type of blown music instrument, a kind of trumpet made of pedu wood with dragon carving on its rod. This music instrument is used at certain moment only, for example in customary rite. Most Tenggerese gamelan music players are youths. This music performance is expected to grow collective characteristics and mentality. Music is expected to internalize customary values as the collective mentality of Tenggerese youth. It, according to Radcliffe Brown[17], is a part of cell regeneration process, in which new cells appear to replace the old dead ones. Thus, this presence of new cells will enable the system of organism to run.

\subsection{Music and Tenggerese Community}

At one night, Tosari youths assembled in Mas Jaya (Tosari youth leader)'s house. Mas Jaya's house is located exactly in front of Tosari Village Office, a strategic place for the youths to assemble. That night is a part of nights on Ramadhan month. They assembled to prepare for walking around the village to wake up the people who will undertake fasting worship to do sahur, although most of youths are Hindu adherents, including Mas Jaya. Besides, the music instrument they used was music instrument used in Tengger Hindu rite, like kendang, gong, and serompet and other simple tools such as kentongan (drum made from bamboo or wood). Even some of them used household appliances such as gallon, pan, frying pan, spoon, etc to be a music instrument. They defined music they played to be patrol music.

Patrol music develops in some areas in East Java: Jember, Mojokerto, Probolinggo and other regions. Located in East Java's territory, Tenggerese community also develops patrol music. In Tosari village, the patrol music activity functions to wake up people to do sahur or round (patrol). Besides, the existence of patrol music enlivens the night circumstance on Ramadhanmonth, moreover, Tosari is a cold and quiet mountains area. Although patrol music is not Tenggerese's original tradition, this cultural activity has been existing since a long time ago and has become Tosari youth tradition. However, patrol music in Tengger acculturates with traditional music instrument like serompet. Somehow, it suggests that music becomes a collective characteristic of Tenggerese youths.

This article does not discuss diffusion or acculturation of patrol music but focuses more on music discussion as a collectivity in community's social structure. Patrol music potentially strengthens the social relationships within community. In Tengger community in Tosari most people of which adhere to Hindu religion, they are tolerant to the existence of patrol music at night on Ramadhan month. Event those playing patrol music to wake up the people who will do sahur are those adhering to Hindu religion. It indicates that the existence of community music teaches tolerance and even pluralism language.

The existence of patrol music in Tengger potentially strengthens social relation within the community. The first relation is that between patrol music players. If the players do not have the feeling of commonness and harmony, the music created will not be harmonious. Moreover, these players of patrol music are youths coming from different religious 
backgrounds. The second relation is that between players and the community as the music consumer. This patrol music is played at night when people take a rest. Moreover, Tenggerese people adhering to Hindu religion do not perform fasting on Ramadhan month. If people cannot accept or feel disturbed by the existence of music, this music will not exist and develop until today or in other word, there will be declination from the people. From this relation, it can be described that harmonization created in patrol music can create harmonization in social relation as well. In other words, natural order will be brought into the social order. This existence of music also becomes one of the entities existing and having a function in the harmonization system in community's life.

\subsection{Music as a Language of Social Harmony}

Music is a form of art that functions in society as a media for peace. Because basically music is a universal language [19]. Through music, humans can articulate their thoughts and feelings stored in memory as part of cultural heritage products and products of social life experience. The articulation process continues with the construction of meaning that is communicated through music and accepted by fellow humans. This research shows that the Tenggerese people who are an indigenous community who occupy Mount Bromo in East Java, they still use music as a language of harmony during the community. As for many who have dealt with similar problems, one of them is Tika Lestari of 2017 [10], which discusses music as a medium of peace in Maluku. Where the collective memory of the Maluku people as family people can be revived if the imagination and cultural emotions of the community are touched by the brotherhood messages based on cultural values contained in the Maluku local music elements. Likewise in this study shows that the cultural emotions of the Tengger indigenous people are touched by the messages conveyed by their young children through music. Do not look at the background of religion and socio-economic status, when celebrating religious holidays or religious moments Tenggerese young relatives channel their cultural expression with music.

In the process of music, young Tengger does not limit one particular type of music and instrument. But the music used is patrol music which is not original music from Tengger. The tools used are also not limited but the harmony created can increase the solidarity of others. The harmony created in music doesn't even matter anymore, because social processes are the main thing. This is different from Sabrina Zerar and Bouteldja Riche's research [9], that Algerian music can explore the performance of spirituality, music instrumentation is very important.

\section{CONCLUSION}

As a customary community, Tenggerese people in Tosari Sub District has value order corresponding to their collective characteristics reflected on their belief, custom, and language. In addition to religious values, Tenggerese customary values are also taught to intermediate generation (youths). As the intermediate generation, the youths have the advantage of being responsive to the change. Tosari people have concept or values underlying their life attitude, "anteng-seger (Tengger)" concept meaning peaceful and prosperous. Antengvalue order can also be defined as calm and not talking too much, that can be elaborated again into concept of "SepiingGunem, RameingGawe" meaning "talk less do more". 
One of the collective characteristics of Tenggerese community members in Tosari is manifested into music art. In addition to having customary music and distinctive Tenggerese music instrument, Tenggerese youths also love playing patrol music, moreover on Ramadhan month. Although it is not Tenggerese original culture, the people, particularly the youths, can accept the presence of patrol music. Patrol music in Tengger acculturates with a local instrument, serompet. Patrol music in Tosari becomes a harmonization language within community. Firstly, harmonization is created in the reflection of tones created by the instrument playing. Secondly, harmonization is created among the players. Harmonization will not be created if the players do not play it compactly. Thirdly, harmonization is created among those consuming the music, moreover, majority Tenggerese people adhere to Hindu religion, and this music is intended to wake up the people to do Sahurworship at night. So, through music system, the harmonization existing within the community can be maintained, and the subject of maintenance is youths.

\section{REFERENCES}

[1]. T. M. Li, "Masyarakat Adat, Difference, and the Limits of Recognition in Indonesia's Forest Zone," Mod. Asian Stud., vol. 35, no. 645-676, 2001.

[2]. A. Bergh and J. Sloboda, "Music and Art in Conflict Transformation: A Review," Music Arts Action, vol. 2, no. 2, pp. 2-18, 2010.

[3]. P. Gilbert, Cultural Identity and Political Ethics. Edinburgh: Edinburgh University Press, 2010.

[4]. J. M. O'Connell, Music and Conflict. Chicago: University of Ilionis Press, 2010.

[5]. D. A. Bell and Y. Mo, "Harmony in the World 2013: The Ideal and the Reality," Soc Indic, vol. 118, no. September 2013, pp. 797-818, 2014.

[6]. S. E. Ramirez, "Imposing Harmony," Eur. Rev. Lat. Am. Caribb. Stud., vol. 88, no. April, pp. 139-142, 2010.

[7]. Soo-Jin Kwon, "An Examination of Cue Redundancy Theory in Cross-Cultural Decoding of Emotions in Music," J. Music Ther., vol. 46, no. 3, pp. 217-237, 2009.

[8]. T. Greg, "Maori Music," p. 1998, 1998.

[9]. S. Zerar and B. Riche, "LOVE AND ISLAM IN TRADITIONAL ALGERIAN MUSIC," Int. J. Arts Sci., vol. 08, no. 03, pp. 229-248, 2015.

[10]. D. Tika Lestari, "Peran Musik Sebagai Salah Satu Media Perdamaian Di Maluku," Institut Seni Indonesia (ISI) Surakarta, 2017.

[11]. M. N. Kholis, "Peran Pemuda Dalam Pemberdayaan Masyarakat Melalui Upacara Adat Dan Implikasinya Terhadap Ketahanan Budaya (Studi Pada Upacara Adat Saparan Ki Ageng Wonolelo Pondok Wonolelo Desa Widodomartani Kecamatan Ngemplak Kabupaten Sleman), Universitas Gadjah Mada, 2018.

[12]. S. Naafs and B. White, "Generasi Antara: Re fl eksi tentang Studi Pemuda Indonesia * Pemuda sebagai Generasi Orang muda adalah aktor kunci dalam,” J. Stud. PEMUDA, vol. I, no. 2, pp. 89$106,2012$.

[13]. J. . Creswell, Research Design : Qualitative, Quantitative and Mixed Methods Approaches : fourth edition. Sage publications, Inc, 2014.

[14]. A. R. Radcliffe-Brown, "Functionalism: A Protest," Am. Anthropol., vol. 51, no. 2, pp. 320-323, 2007.

[15]. J. Scott, Teori Sosial: Masalah-masalah Pokok dalam Sosiologi. Yogyakarta: Pustka Pelajar, 2012.

[16]. R. B. M, Child, Family, School, Community, Socialization and Support. Wadsworth: Cengage Learning.

[17]. J. Van Ball, Sejarah dan Pertumbuhan Teori Antropologi Budaya Jilid 2. Jakarta: Gramedia, 1998.

[18]. K. Saddhono, "Language of Coastal Communities in the Northern Coast of Central Java: Sociolinguistic Studies in Cultural Integration Maritime-Agrarian Perspective." Adv. Sci. Let. vol. 23 no.10 pp 10054-10056, 2017 
